\title{
Elementary School Physical Education Teachers' Attitudes toward the Use of Mobile Learning during COVID-19 Pandemic
}

\author{
Gita Febria Friskawati $^{1, *}$, Vicki Akhmad Karisman ${ }^{1}$, Dedi Supriadi ${ }^{2}$, Mesa Rahmi Stephani ${ }^{3}$ \\ ${ }^{1}$ Department of Physical Education, Health and Recreation STKIP Pasundan, Jln. Permana, No. 32B, Citeureup, Cimahi Utara, \\ West Java, Indonesia \\ ${ }^{2}$ Department of Postgraduate STKIP Pasundan, Jln. Permana, No. 32B, Citeureup, Cimahi Utara, West Java, Indonesia \\ ${ }^{3}$ Department of Physical Education for Elementary School, Universitas Pendidikan Indonesia, Jl. Dr. Setiabudi No.229, Isola, Kec. \\ Sukasari, Bandung, West Java, Indonesia
}

Received September 22, 2020; Revised November 19, 2020; Accepted December 27, 2020

\section{Cite This Paper in the following Citation Styles}

(a): [1] Gita Febria Friskawati, Vicki Akhmad Karisman, Dedi Supriadi, Mesa Rahmi Stephani, "Elementary School Physical Education Teachers' Attitudes toward the Use of Mobile Learning during COVID-19 Pandemic," International Journal of Human Movement and Sports Sciences, Vol. 9, No. 3, pp. 488 - 494, 2021. DOI: 10.13189/saj.2021.090314.

(b): Gita Febria Friskawati, Vicki Akhmad Karisman, Dedi Supriadi, Mesa Rahmi Stephani (2021). Elementary School Physical Education Teachers' Attitudes toward the Use of Mobile Learning during COVID-19 Pandemic. International Journal of Human Movement and Sports Sciences, 9(3), 488 - 494. DOI: 10.13189/saj.2021.090314.

Copyright $\bigcirc 2021$ by authors, all rights reserved. Authors agree that this article remains permanently open access under the terms of the Creative Commons Attribution License 4.0 International License

\begin{abstract}
Physical education teaching and learning in the new normal era requires teachers to hold online learning. Most teachers choose mobile learning in spite of its debatable pro and contra in responding to it. The purpose of this study was to describe the attitudes of elementary school physical education teachers towards the use of mobile learning during the COVID-19 pandemic. The teachers' attitude was also examined based on their gender, age, and teaching experience. A survey was conducted on 71 physical education teachers across West Java, Indonesia. All physical education teachers had agreed to be involved in this research and were willing to provide information about their attitudes towards the use of mobile learning during the COVID-19 pandemic. The instrument used in this study, Physical Education Teachers' Subjective Theories Questionnaire (PETSTQ), was distributed online using Google Form from June to July 2020. Kruskal-Wallis and Mann-Whitney U non-parametric were used to reveal the differences in attitudes towards mobile learning in physical education learning during COVID-19. The results showed that the attitudes of elementary physical education teachers varied based on gender, age, and teaching experience. The findings of this study can inform policy makers to formulating a more applicable online physical education system during the COVID-19 pandemic.
\end{abstract}

Keywords Elementary School Physical Education Teachers, Attitudes, Mobile Learning

\section{Introduction}

The rapid spread of Covid 19 has led to the temporary closure of schools throughout the world. That elementary school children aged 6-12 years who are vulnerable to the virus is a major issue for school closures worldwide [1]. Empirically, the strategy is believed to limit social distancing between students. These social distancing Information and Communication Technologiesions will help flatten the curve and reduce the death rate as a result of COVID-19 infection [2]. Consequently, there will be a new learning process paradigm in elementary schools that will overturn policies, regulations, and learning platforms as a solution to this problem [3]. The teaching and learning process is directed at online learning that utilizes digital technology and global classrooms, which can take the form of using online learning through various media such as the use of Google meetings, Zoom, WhatsApp, and other online media [4]. Teachers are not only preparing online learning material, but also encouraging 
students to apply personalized learning through more flexible education system. A flexible independent learning system is not limited by space and time because it is carried out anywhere. Personalized learning still refers to the readiness and students characteristics so that it can be carried out well and students have the motivation to follow it [5]. Personalized learning is bundled through a platform that can convey information clearly to students. This learning is embalmed with adjustments to the surrounding environment and becomes one of the learning strategies to maintain social distancing between students [4].

The selection of online media for primary schools is important to motivate students to learn online at home. Clear learning objectives and appropriate media are among effective strategies to facilitate students motivation [5]. One of the online media used by most teachers in Indonesia, especially in Java, is the use of mobile learning [6]. Mobile learning is the use of technologies in a educational context, [7]. Physical education teachers use mobile learning as a tool, manipulation, and information processing. This utilization can be in the form of videos, animation, tutorials, simulation and links to material relevant to children's development in the form of power points and Microsoft Word [8], [9]. The content presented both through videos and links are facilitated through mobile learning tailored to the development of elementary school students so that learning objectives can be achieved [10], [11]. Typically, teachers use social media to distribute materials and assignments, such as Facebook, Instagram and WhatsApp [12]. Evaluation in each process and learning tools can solve learning problems[13]. Teachers and students are separated physically yet they are connected online.

The success or failure indicator of mobile learning implementation is teachers' attitude [14]. Studies have shown that physical education teachers' attitudes toward Information and Communication Technologies integration is getting positive [14], [15]. Nowadays, the increasing use of Information and Communication Technologies equipment for physical education learning processes such as heart rate monitors, pedometers, and mobile applications has been widely used by Physical Education teachers, although the use of such tools cannot be simply generalized to all levels but it must be attuned to the students' characteristics [16].

The teachers' view that learning with the integration of Information and Communication Technologies $\mathrm{S}$ will be more effective than traditional learning is the main issue for the transition of technology-based learning for modern learning [17], [18]. The reason is that technology-based learning media such as the use of computers, videos, animation, projectors, etc. will provide full information to students through comprehensive senses (visual, auditory, tactile, etc)[19], [20].

In addition, some physical education teachers have a negative attitude towards the use of technology in physical education learning. This attitude is indicated by the number of physical education teachers who feel they do not have sufficient competence to use technology into learning [16], [21]. Most of them consider that pedagogical adjustment is necessary to optimize the use of technology in physical education [22]. The role of teachers can also be shifted by technology when the teachers was the main source of information switching to Information and Communication Technologies and the teacher only acts as a learning facilitator [23]. The inadequate availability of equipment and supporting equipment for the integration of Information and Communication Technologies into physical education learning at every school level is the major challenge for teachers to implement it [14].

Research on physical education teachers' behavior towards Information and Communication Technologies use, including mobile learning, is mostly carried out in junior and senior high schools [14], [16]. In fact, the use of technology such as mobile learning is essential to be introduced in elementary school students so that they will be more confident and able to adapt to the accelerated development of technology around them and are able to equip themselves to prepare for the use of technology at the next level [24]. Especially during the current Covid 19 pandemic which requires all students at the school level to use technology in every lesson.

There is a necessity for teachers to be able to create teaching content that is in accordance with the development of elementary school students through online media. Teacher readiness will be influenced by their perspective and attitudes towards the application of technology in learning [18], [19]. A survey has also been conducted on the integration of technology in learning regardless of gender and teaching experience, the result is $92 \%$ respondents said that the application of technology into learning is deemed important to provide new teaching opportunities for students in schools[24]. In this study, mobile learning refers to education conducted by means of portable computing devices such as smart phones, tablets, application that used in physical education. It is necessary to draw a basic school Physical Education teacher's attitude so that they can be more creative and innovate to create meaningful Physical Education learning during the COVID-19 pandemic.

\section{Material and Method}

\section{Participant and Procedure}

The research was conducted to 71 elementary school physical education teachers in West Java, Indonesia. The sample consisted of 43 male and 28 female teachers from such regions in West Java as Bandung City, Cimahi City, West Bandung Regency, Garut, Sumedang, and 
Majalengka. The age ranges are divided into 24-30 years old in the young category, 31-40 years in the middle category, 41-50 years in the old category[25]. Their age ranges varied, as many as 33 people aged between 24-30 years, 20 people aged between $31-40$ years, and 18 people aged between 41-50 years. Teaching experience was also seen in this study, as many as 47 people have taught Physical Education for 15-25 years, 24 people for between 3-14 years. The entire sample was willing to take part in the research.

\section{Measures}

The instrument used was the Physical Education Teachers 'Subjective Theories Questionnaire (PETSTQ) to measure participants' perspectives on Information and Communication Technologies integration including the use of mobile learning into physical education learning that has reability $p=0.89$ [16]. This instrument was distributed via Google Form from June-July 2020. Before filling out the instrument, the teachers fill out their personal information in advance about gender, age, teaching experience and the area of teaching. The survey data obtained were processed using the Statistical Package for the Social Sciences (SPSS 20.0). First, the data described to determine the mean, standard deviation and normality. Second, the data processed using non-parametric Kruskal-Wallis and Mann-Whitney U. P value. if the value is $<0.05$, it can draw statistical conclusions on the proposed hypothesis.

\section{Results and Discussion}

The data from the distribution of the PETSTQ instrument are described as mean and standard deviation to see the various data distributions given by each variable to be measured as well as to see whether the data is normally distributed[26]. Data means, standard deviation and variance were calculated through statistical descriptions in the SPSS 20.0 program. The results show that the mean is 189 and the standard deviation is 52.3. Normality has also been calculated using the Shapiro Wilk tests and the results showed that $(p<0.05) p=0.01$. It means that the data was normally distributed. Furthermore, to determine the differences in gender, age, length of teaching experience and place of teaching on the attitudes of elementary school Physical Education teachers in the use of mobile learning in learning, the calculation uses the Mann Whitney $U$ tests on each PETSTQ indicator, namely (a) classroom management; (b) computer literacy; (c) supporting equipment; (d) innovative learning; (e) student readiness; and (f) social interactions.

\section{Gender}

Gender differences in physical education teachers' attitudes towards the use of mobile learning during the COVID-19 pandemic were calculated using the Mann Whitney $U$ tests. The attitude of physical education teachers towards the application of technology including the use of mobile learning varied based on gender [18]. The data are displayed in table 1 .

Table 1. Median and Range based on gender

\begin{tabular}{ccccc}
\hline & \multicolumn{2}{c}{$\begin{array}{c}\text { Male } \\
(n=43)\end{array}$} & \multicolumn{2}{c}{$\begin{array}{c}\text { Female } \\
(n=28)\end{array}$} \\
\cline { 2 - 5 } Indicators & Median & Range & Median & Range \\
\hline $\begin{array}{c}\text { Classroom } \\
\text { Management } \\
\text { Computer } \\
\text { literate } \\
\text { Supporting } \\
\text { facilities } \\
\begin{array}{c}\text { Innovative } \\
\text { learning }\end{array}\end{array}$ & 3.40 & $1.25-5.00$ & 3.00 & $1.40-5.00$ \\
$\begin{array}{c}\text { Students } \\
\text { Readiness } \\
\text { Social }\end{array}$ & 3.55 & $1.50-5.00$ & 3.15 & $1.00-4.70$ \\
Interaction & 3.15 & $2.00-5.00$ & 3.67 & $1.20-5.00$ \\
\hline
\end{tabular}

The difference in the attitudes of physical education teachers towards the use of mobile learning in learning during the COVID-19 pandemic based on gender in each indicator shows that each indicator shows the median value of male teachers is greater than female teachers with Classroom Management having a value of $U=1543.7, p$ $=0.009$; Technological literacy has a value of $U=1876$, $p=0.010$; Support equipment has a value of $U=15654, p$ $=0.015$; Innovative Learning has a value of $U=1953, p=$ 0.006 ; Student readiness has a value of $U=1338.9, p=$ 0.011 ; Social interaction has a value of $U=19876, p=$ 0.019 . The data also shows that female teachers $(m d n=$ 3.25 , Range $=1.00-5.00$ ) show a greater median than male teachers $(m d n=3.20$, Range $=1.00-4.80)$ on innovative learning. In conclusion, there is a significant difference between gender and Physical Education teacher attitudes towards the use of mobile learning during the COVID-19 pandemic.

The results based on all indicators show male teachers are more positive than female teachers in the use of mobile learning in physical education learning during this pandemic. This result is in accordance with previous research which revealed that male teachers have more positive attitudes than female teachers towards technology integration in physical education learning[16]. The use of technology in learning through mobile learning is more frequently used in the form of giving assignments via social media carried out by male teachers compared to female teachers [15]. Male teachers are also more confident in operating technology and are able to learn independently to implement it into learning than female teachers [27]. This study shows that gender differences in addressing the use of mobile learning in Physical Education learning still exist even though their daily lives cannot be separated from gadgets. Therefore, this study 
suggests creating a special intervention program for female Physical Education teachers according to their needs in making Physical Education learning through mobile learning. This program can contain an introduction to the use of social media for physical education learning, video content creation, material delivery via power point or pdf which is shared using Google form, etc.[10].

\section{Age}

This study also took into account differences in attitudes based on age. The age division is divided into three groups, namely: 24-30 years old, 31-40 years old, and 41-50 years old. It is important to divide the age ranges to see differences in perceptions of the use of technology in learning [18]. The data is described in table 2.

The calculation of the Kruskal-Wallis $H$ test was carried out to show the effect of the age of elementary school Physical Education teachers on their attitudes towards the use of mobile learning during the Covid19 pandemic. The results show that there is a significant relationship between teacher age and their attitudes towards the use of mobile learning at technology literacy points with a value of $\mathrm{H}=13,876, \mathrm{p}=0.0012$ the mean rank is 184.76 for teachers aged 24-30 years, the mean rank is 211.01 for teachers aged 31-40 years, and 245.88 for teachers aged 41-50 years. After that, a post-hoc test was conducted to see differences in teacher attitudes according to age ranges. As a result, the attitudes of teachers aged 41-50 years have lower scores than teachers aged 31-40 years and 24-30 years with scores $(p=0.0001)$. This means that teachers in the age range 41-50 in the old age category have a negative attitude towards the use of mobile learning in physical education learning during Covid19 compared to teachers in the middle and young age category.

Differences in perceptions about the use of technology into the physical education teaching and learning process will inevitably emerge according to a person's characteristics, gender, age and experience while teaching [28]. These results indicate that teachers in the old age category have negative attitudes towards the use of technology in Physical Education learning. The reason is, teacher do not have confidence in increasing their competencies to integrate technology into physical education learning[27].Teachers are also confused to choose the appropriate technology because there is no specific training for it [29]. Meanwhile, for younger teachers, it is easier for them to learn independently and innovate in making plans and materials that will be delivered online through mobile learning tailored to the students' characteristics[16]. Even so, there are young physical education teachers who have little experience in operating technology into physical education learning because of limited equipment and teaching areas [30]. This study suggested that all Physical Education teachers in each age range category (young, middle, and old) can increase self-confidence to use mobile learning in Physical Education learning by getting used to using gadgets in the Physical Education learning process. With this habituation, teacher can develop their skills in using technology, especially mobile learning in Physical Education learning [27].

Table 2. Median and Range based on Age

\begin{tabular}{|c|c|c|c|c|c|c|}
\hline \multirow[b]{2}{*}{ Indikator } & \multicolumn{2}{|c|}{$\begin{array}{c}24-30 \text { tahun } \\
\quad(n=33)\end{array}$} & \multicolumn{2}{|c|}{$\begin{array}{c}31-40 \\
(n=20) \\
\end{array}$} & \multirow{2}{*}{$\begin{array}{c}\begin{array}{c}41-50 \\
(n=18)\end{array} \\
\text { Median }\end{array}$} & \multirow[b]{2}{*}{ Range } \\
\hline & Median & Range & Median & Range & & \\
\hline $\begin{array}{c}\text { Classroom } \\
\text { Management }\end{array}$ & 3.10 & $1.65-4.40$ & 3.11 & $1.42-5.00$ & 3.00 & $1.20-5.00$ \\
\hline Computer literate & 3.60 & $1.00-5.00$ & 3.20 & $1.45-5.00$ & 3.15 & $1.50-5.00$ \\
\hline Supporting facilities & 3.90 & $1.30-4.40$ & 3.60 & $1.70-5.00$ & 3.10 & $1.50-5.00$ \\
\hline Innovative learning & 3.85 & $1.00-5.00$ & 3.25 & $1.00-4.00$ & 3.00 & $1.25-5.00$ \\
\hline Students' Readiness & 3.45 & $1.30-5.00$ & 3.50 & $1.05-5.00$ & 3.50 & $1.15-5.00$ \\
\hline Social Interaction & 3.33 & $1.46-5.00$ & 3.25 & $1.00-5.00$ & 3.10 & $1.05-5.00$ \\
\hline
\end{tabular}


Table 3. Median and Range based on Teaching Experience

\begin{tabular}{|c|c|c|c|c|}
\hline \multirow{2}{*}{ Indicators } & \multicolumn{2}{|c|}{$\begin{array}{c}\text { 3-14 Years } \\
(n=24)\end{array}$} & \multicolumn{2}{|c|}{$\begin{array}{c}15-25 \text { years } \\
(n=47)\end{array}$} \\
\hline & Median & Range & Median & Range \\
\hline Classroom & 3.55 & $1.60-5.00$ & 3.55 & $1.74-$ \\
\hline Management & & & & 5.00 \\
\hline Computer literate & 3.80 & $1.00-5.00$ & 3.45 & $\begin{array}{l}1.05- \\
5.00\end{array}$ \\
\hline $\begin{array}{c}\text { Supporting } \\
\text { facilities }\end{array}$ & 3.60 & $1.85-4.70$ & 3.70 & $\begin{array}{l}1.80- \\
5.00\end{array}$ \\
\hline Innovative learning & 3.10 & $1.95-5.00$ & 3.00 & $\begin{array}{l}1.00- \\
5.00\end{array}$ \\
\hline Students' & 3.15 & $1.70-5.00$ & 3.15 & $1.35-$ \\
\hline Readiness & & & & 4.40 \\
\hline Social Interaction & 3.30 & $1.90-5.00$ & 3.48 & $\begin{array}{l}1.20- \\
5.00\end{array}$ \\
\hline
\end{tabular}

\section{Teaching Experience}

Teaching experience is also one of the factors observed to see teacher's attitudes towards the use of mobile learning during Covid 19 [14]. Data obtained from a sample of 47 people teaching Physical Education for 15-25 years and 24 people between 3-14 years. All data were processed using the Mann - Whitney $U$ tests and they are presented in table 3 .

Table 3 shows that there are differences in teacher's attitudes toward using mobile learning on technological literacy for teacher with 3-14 year experience $(m d n=3.80$, Range $=1.00-5.00)$ with greater median and rank compared to median and rank for teacher with 15-25 year experience $\quad(m d n=3.45, \quad$ Range $=1.00-5.00) \quad$ with $\mathrm{U}=1476.88, \mathrm{p}=0,000$. In supporting equipment indicator, it revealed that the median and range are $m d n=3.60$, Range $=1.00-5.00$ dengan $\mathrm{U}=1625.8, \mathrm{p}=0.002$ for teacher with 3-14 years of experience; and $m d n=3.70$, Range $=1.80-5.00$ with $\mathrm{U}=1445.87, \mathrm{p}=0.001$. For teacher with 15-25 years of experience. Innovative learning indicator shows that the median and range $m d n=3.10$, Range $=1.95-5.00)$ with $\mathrm{U}=1554.9, \mathrm{p}=0,012$ for teacher with 3-14 years of experience; and $m d n=3.00$, Range $=1.00-5.00$ with $\mathrm{U}=1674.5, \mathrm{p}=0,016$ for teacher with 15-25 years of experience. Social interaction indicator reveals that $m d n=3.30$, Range $=1.90-5.00$ with $\mathrm{U}=1765.77, \mathrm{p}=0.019$ for teacher with 3-14 years of experience; and $m d n=3.48$, Range $=1.20-5.00$ with $\mathrm{U}=1777.9, \mathrm{p}=0.0021$ for teacher with $15-25$ years of experience. To conclude, there are differences in attitudes between teaching experiences and teachers' attitudes on the implementation of mobile learning during the Covid19 pandemic.

The teacher's attitude towards the use of mobile learning in learning is revealed in a variety of ways based on their teaching experience. The greatest positive attitude was shown by the 3-14 years teaching experience group, especially in technology literacy indicator compared to the 15-25 year group. This indicates that the long teaching experience of Physical Education teachers does not guarantee that they can operate technology, especially mobile learning, into the Physical Education learning process during the COVID-19 pandemic [18]. Innovative learning can be provided by teachers who have little teaching experience but have skills in integrating technology into better learning. Teachers are more able to develop learning by using various features available on their gadgets, such as the use of online learning using the Google Class and the use of self-made digital applications [11]. In the aspect of student readiness when learning to use mobile learning and classroom management, teachers who have long and brief experiences have the same positive attitude. Think about choosing material that is tailored to the character of elementary school students so that they are able to package learning that can lead students to learning situations virtually [21]. The results suggest that technology literacy should be started as early as possible to develop their knowledge, confidence and motivation in operating technology and applying it consistent with the students' needs and characteristics.

\section{Conclusion}

The COVID-19 pandemic should not be an excuse not conduct to teaching and learning processes. The positive attitude of teachers towards the use of technology, especially mobile learning, into the physical education teaching and learning process is the main key to the success in virtual learning. The results showed that there were differences in the attitudes of elementary school 
physical education teachers seen from gender, age, and length of teaching based on such indicators as (a) classroom management; (b) computer literacy; (c) supporting equipment; (d) innovative learning; (e) student readiness; and (f) social interactions. These differences in attitude have become an illustration for policy makers such as headmaster on the implementation of online learning, especially physical education, to review the learning system so as to improve the quality of learning.

Differences in physical education teachers' attitudes towards the use of mobile learning in the aspects of gender, age, and length of teaching have been revealed in this study. However, the location of the teachers' teaching area which is the reason for not implementing online learning due to limited equipment has not been revealed. Therefore, it is suggested that further research be able to reveal teachers' attitudes towards the use of mobile learning during the pandemic in terms of the teaching area.

\section{REFERENCES}

[1] J. Bayham and E. P. Fenichel, "Articles Impact of school closures for COVID-19 on the US health-care workforce and net mortality : a modelling study," Lancet Public Heal., vol. 2667, no. 20, pp. 1-8, 2020, doi: 10.1016/S2468-2667(20)3 0082-7.

[2] P. Suppawittaya, P. Yiemphat, and P. Yasri, "Effects of Social Distancing, Self-Quarantine and Self-Isolation during the COVID-19 Pandemic on People's Well -Being, and How to Cope with It," vol. 5, no. June, pp. 12-20, 2020.

[3] C.-P. Georgia, "Transition to Online Education in Schools during a SARS-CoV-2 Coronavirus Transition to Online Education in Schools during a SARS-CoV-2 Coronavirus ( COVID-19 ) Pandemic in Georgia," no. April, 2020, doi: $10.29333 / \mathrm{pr} / 7937$.

[4] Z. Almarzooq, M. Lopes, and A. Kochar, "Virtual Learning During the COVID-19 Pandemic : A Disruptive Technology in," J. Am. Coll. Cardiol., no. April, 2020, doi: 10.1016/j.jacc.2020.04.015.

[5] G. Colquitt, T. Pritchard, C. Johnson, and S. Mccollum, "Differentiating Instruction in Physical Education: Personalization of Learning Differentiating Instruction in Physical Education: Personalization of Learning," no. September, 2017, doi: 10.1080/07303084.2017.1340205.

[6] S. R. Rahman, "Pembelajaran Online di Tengah Pandemi Covid-19," vol. 2, no. 2, pp. 81-89, 2020.

[7] T. Goad, B. Towner, and E. Jones, "Instructional Tools for Online Physical Education:," vol. 3084, 2019, doi: 10.1080/07303084.2019.1614118.

[8] X. Zhu and L. A. Dragon, "Physical activity and situational interest in mobile technology integrated physical education : A preliminary study," Acta Gymnica, vol. 46, no. 2, pp. 5967, 2016, doi: 10.5507/ag.2016.010.

[9] I. Journal, M. F. Lorenzo, C. M. Trujillo, M. F. Lorenzo, and
C. M. Trujillo, "Cognitive Processes, ICT, and Education : A Critical Analysis," Comput. Sch., vol. 0, no. 0, p. 18, 2018, doi: 10.1080/07380569.2018.1491772.

[10] S. Bell et al., "Sustainability and distance learning : a diverse European experience? Sustainability and distance learning : a diverse European," Open Learn. J. Open, Distance e-Learning, vol. 32, no. 2, pp. 95-102, 2017, doi: $10.1080 / 02680513.2017 .1319638$.

[11] M. Arzayeva, K. Rakhimzhanov, and A. Abdrahmanova, "Special Aspects of Distance Learning in Educational System," vol. 73, 2017, doi: 10.1080/09720073.2015.11891 900

[12] V. Kumar and P. Nanda, "Social Media in Higher Education," no. November, 2018, doi: 10.4018/IJICTE.201 9010108

[13] Muslimin and Destriana, "Evaluation of curriculum implementation of 13 sports and health education teachers," Univers. J. Educ. Res., vol. 8, no. 1, pp. 27-35, 2020, doi: 10.13189/ujer.2020.080104.

[14] N. X. Tou and M. Camire, "Singapore teachers ' attitudes towards the use of information and communication technologies in physical education," 2019, doi: $10.1177 / 1356336$ X19869734.

[15] H. Bisgin, "Analyzing the Attitudes of Physical Education and Sport Teachers towards Technology Analyzing the Attitudes of Physical Education and Sport Teachers towards Technology," Anthropol. ISSN, vol. 73, no. 18, pp. 761-764, 2017, doi: 10.1080/09720073.2014.11891607.

[16] R. Kretschmann, "PHYSICAL EDUCATION TEACHERS' SUBJECTIVE THEORIES ABOUT INTEGRATING INFORMATION AND COMMUNICATION TECHNOLO GY ( ICT ) INTO PHYSICAL EDUCATION," Turkish Online J. Educ. Technol., vol. 14, no. 1, pp. 68-96, 2015.

[17] Y. Ju and H. Wan, "Analysis of Physical Education Teaching Mode Based on Computer Multimedia and Network System," Int. J. Database Theory Appl., vol. 9, no. 10, pp. $397-408,2016$.

[18] J. Baek, E. Jones, S. Bulger, and A. Taliaferro, "Physical Education Teacher Perceptions of Technology-Related Learning Experiences: A Qualitative Investigation," $J$ Teach. Phys. Educ., vol. 37, no. 2, pp. 175-185, 2018.

[19] J. Wyant and J. Baek, "Re-thinking technology adoption in physical education," Curric. Stud. Heal. Phys. Educ., vol. 0, no. 0, pp. 1-15, 2018, doi: 10.1080/25742981.2018.151498 3.

[20] A. Kukulska-hulme et al., Innovating Pedagogy policy makers. 2020.

[21] A. Casey, V. A. Goodyear, K. M. Armour, A. Casey, V. A. Goodyear, and K. M. Armour, "Rethinking the relationship between pedagogy, technology and learning in health and physical education Rethinking the relationship between pedagogy , technology and learning in health and physical education," Sport. Educ. Soc., vol. 0, no. 0, pp. 1-17, 2016 , doi: 10.1080/13573322.2016.1226792.

[22] J. Koekoek, H. Van Der Mars, J. Van Der Kamp, W. Walinga, and I. Van Hilvoorde, "Aligning Digital Video Technology with," vol. 3084, 2018, doi: 
$10.1080 / 07303084.2017 .1390504$.

[23] D. Lupton, "Data assemblages, sentient schools and digitised health and physical education (response to Gard)," no. December 2014, pp. 37-41, 2015, doi: $10.1080 / 13573322.2014 .962496$.

[24] N. S. Emery and N. S. Emery, "Technological Literacy Programs in Elementary School," 2016.

[25] R. L. Rosa, D. De Gaetano, and Z. Rodr, "Deep Learning," no. May, 2017, doi: 10.1109/ACCESS.2017.2706674.

[26] P. C. Dunn, S. M. Knight, and K. Vail-Smith, "Journal of American College Health. 47.5,” no. c, pp. 1-10, 1999.

[27] A. Villalba and M. D. González-rivera, "Obstacles Perceived by Physical Education Teachers to Integrating ICT," Turkish Online J. Educ. Technol., vol. 16, no. 1, pp.
83-92, 2017.

[28] B. A. Dube, E. Nhamo, and S. Magonde, "Factors affecting ICT integration in the Teaching and Learning of Physical Education in South Africa: A Case of Johannesburg East Cluster Primary Schools in the Gauteng Province," vol. 2, no. 1, pp. 88-92, 2018.

[29] P. Legrain, N. Gillet, and C. Gernigon, "Integration of Information and Communication Technology and Pupils' Motivation in a Physical Education Setting Self-Determination Theory," J. Teach. Phys. Educ., vol. 34, no. 3, pp. 384-401, 2015.

[30] M. Chia, "Information and Communications Technology and Physical Education in Singapore Information and Communications Technology and Physical Education in Singapore," Media Asia, vol. 6612, no. August, pp. 94-98, 2017, doi: 10.1080/01296612.2000.11771953. 